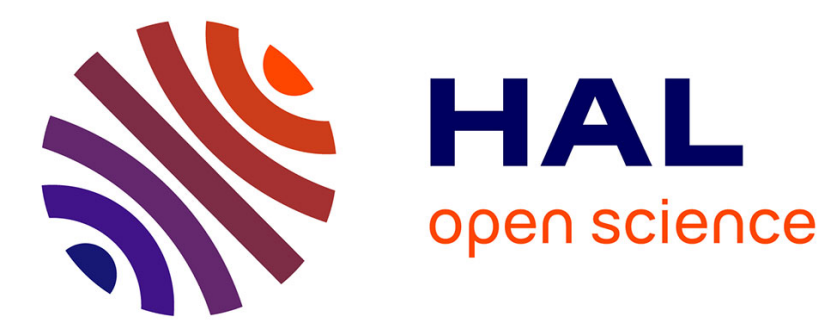

\title{
Specificities of parasitism in goats and sheep: Interactions with nutrition and control strategies
}

Pilar Frutos, Hervé Hoste, Smaragda Sotiraki, Martin Hall, F. Jackson

\section{To cite this version:}

Pilar Frutos, Hervé Hoste, Smaragda Sotiraki, Martin Hall, F. Jackson. Specificities of parasitism in goats and sheep: Interactions with nutrition and control strategies. Small Ruminant Research, 2012, 103, pp.1-2. hal-01512044

\section{HAL Id: hal-01512044 \\ https://hal.science/hal-01512044}

Submitted on 21 Apr 2017

HAL is a multi-disciplinary open access archive for the deposit and dissemination of scientific research documents, whether they are published or not. The documents may come from teaching and research institutions in France or abroad, or from public or private research centers.
L'archive ouverte pluridisciplinaire HAL, est destinée au dépôt et à la diffusion de documents scientifiques de niveau recherche, publiés ou non, émanant des établissements d'enseignement et de recherche français ou étrangers, des laboratoires publics ou privés. 


\section{Specificities of parasitism in goats and sheep: Interactions with nutrition and control strategies ${ }^{\text {th }}$}

This special issue (SI) of Small Ruminant Research aims at illustrating the complexity of parasitism and its control in goats and sheep. This topic should be a fruitful field of future multidisciplinary research given the changes that small ruminant breeders will have to face. We hope that it provides useful practical information, which if applied, will help achieve sustainable extensive production systems for sheep and goats.

This special issue is the compilation of selected topics from two separate conferences held in October 2009. One was the first meeting of the European COST Action CAPARA, "Goat-parasite interactions: from knowledge to control", held in Thessaloniki (Greece), and the other was the 13th Seminar of the FAO-CIHEAM subnetwork on Sheep and Goat Nutrition, "Challenging strategies to promote the sheep and goat sector in the current global context", held in Leon (Spain).

The first group of papers shows that nutritional manipulation could be a tool to control gastrointestinal parasite infections in sheep and goats, reducing their dependence on conventional chemotherapy and supporting the sustainable control of parasites. Several articles in this group focus on the manipulation of the feeding of these two small ruminant species to transform the dynamics of helminth infections and to improve host response (either resistance or resilience) towards parasites. The review by Houdijk addresses the question whether host resistance to gastrointestinal nematodes is equally sensitive to metabolizable protein or metabolizable energy scarcity and suggests that the greatest benefits of supplementation are expected to come from protein-rich foods rather than from energy-rich foods. The review by Torres-Acosta et al. explores the potential of grazing management in hot humid and sub-humid tropical regions to reduce dependency on

is This paper is part of the special issue entitled Specificities of parasitism in goats and sheep: Interactions with nutrition and control strategies, Guest Edited by Pilar Frutos, Hervé Hoste, Smaragda Sotiraki and Martin Hall and Frank Jackson. anthelmintic drugs, and shows that the choice of protein or energy supplementation depends to a great extent on the environment.

Three papers discuss the concept of nutraceutical, which here refers to plants with antiparasitic properties that are used for their beneficial effects on animal health rather than for their direct nutritional value, and is a novel approach in veterinary sciences. In line with this, the review by Moreno-Gonzalo et al. summarizes the anthelmintic and nutritional effects of heather supplementation in grazing goats naturally infected with gastrointestinal nematodes.

The hypothesis that sheep and goats might adapt either by physiological processes or by feeding behaviour, and the differences between the two species, is discussed in two articles. The first one, by Alonso-Diaz et al., analyzes the amino acid profile of the saliva of goats and sheep and its interaction with tannins in an attempt to link the profile to differences between the two species, not only in feeding behaviour but also in the anthelmintic activity of dietary tannins. The second article, by Villalba and Landau, assesses whether parasitized farm animals are able to display self-medicative behaviours, as it has been shown that consuming certain plant secondary metabolites has the potential to increase animal fitness, as they may act against parasites.

It is also hypothesized that the complex interactions between ruminant outdoor nutrition and exposure to parasite infection have resulted in different evolutionary and selective processes whose consequences are still perceptible between sheep and goats today under current breeding conditions. This hypothesis underpins the second group of articles that compose this special issue. They illustrate how long-term differences in feeding behaviour, between a mostly grazing species (sheep) and a semibrowsing species (goat), have led to major differences in host metabolism, host-parasite relationships and efficiency of chemical control. This is first illustrated by the model of gastrointestinal infection with nematodes, in regard of compared diagnostic tools (see the paper by Hope 
et al.) and/or the efficiency of control measures in sheep and goats. The consequences of differences in the ability of the animals to detoxify xenobiotics and, in turn, their consequences for the efficiency of the usual methods of control are addressed in the article by Lespine et al. which illustrates the need to adapt the posology of anthelmintic drugs in goats, and in that by Jackson et al., which compares the status of anthelmintic resistance in the two ruminant species. Lastly, the article by Rinaldi and Cringoli presents a novel mode to apply the treatment to achieve a more sustainable control. The specificities of goats in their interactions with non-helminth parasites are also discussed in the case of ectoparasites by Sotiraki and Hall, and in the case of digestive protozoa by Paraud and Chartier.

The articles in this special issue illustrate the specificities of parasitism in goats and sheep under a range of different environments (e.g. temperate, Mediterranean and tropical conditions) and breeding systems. They summarize the current state of knowledge on the subject and suggest further directions of research as well as the development of efficient strategies to benefit from these specificities.

\section{Acknowledgments}

Our thanks to all of those who took the time to review the articles submitted: M. Alvinerie, H. Ben Salem, J. Burke, R. Celaya, A.J. Duncan, H. Enemarck, I. Ferre, M. Franc, C. Gokbulut, H. Hertzberg, J. Hoglund, R. Kaplan, S.Y. Landau, Y. LeFrileux, M. Mahieu, A. Markovics, A. Moreno, K. Pfister, A.R. Sykes, T.H. Terrill, S.M. Thamsborg, J.F.J. Torres-Acosta, J. Vercruysse.
Guest Editor

Pilar Frutos*

Instituto de Ganadería de Montaña

(CSIC-ULE), Finca Marzanas, $s / n$. 24346-Grulleros, León, Spain

Guest Editor

Hervé Hoste

UMR 1225 IHAP INRA/ENVT, 23 chemin des Capelles, 31076 Toulouse, Cedex, France

Guest Editor

Smaragda Sotiraki

Veterinary Research Institute, National Agricultural Research Foundation (NAGREF), NAGREF Campus, 57001 Thermi, Thessaloniki, Greece

Guest Editor

Martin Hall

Natural History Museum, Cromwell Road, London SW7 5BD, UK

Guest Editor

Frank Jackson

Moredum Research Institute, Penuicick, Bushloan, Edinburgh, UK

* Corresponding author. E-mail addresses: p.frutos@csic.es

(P. Frutos), h.hoste@envt.fr (H. Hoste), sotiraki@vri.gr (S. Sotiraki), m.hall@nhm.ac.uk (M. Hall)

Frank.Jackson@moredun.ac.uk (F. Jackson) Available online 15 November 2011 